\title{
The Phenomenon of Mobility, a Development Challenge for the City Of Algiers
}

\author{
* Ph.D. candidate OUAFA LOUAFI \\ University of Salah BOUBNIDER, Constantine, Algeria \\ E mail: ovafa.lovafi@univ-constantine3.dz
}

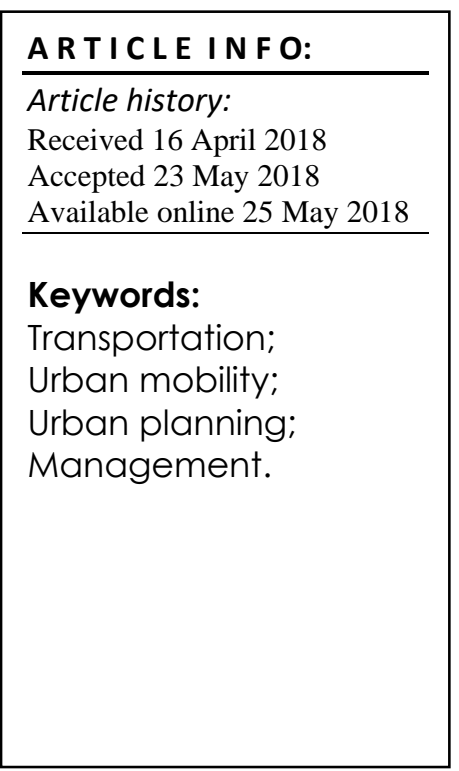

This work is licensed under a Creative Commons Attribution - NonCommercial - NoDerivs 4.0. "CC-BY-NC-ND"

\begin{abstract}
A B S T R A C T
Urban displacements are a major challenge for the economic and social development of the city and are a sign of quality of life. They are defined by less congestion, less pollution, congestion and urban sprawl. In Algeria, the new urban policies are seen as the beginning of a positive transformation of the city's situation, which degradation seems to have origin in a lack of coordination between planning, the deregulation of the transport sector and the urban planning of cities. Therefore, it is necessary to develop a transportation policy based on a logic of sustainable development of the urban area where the optimization of mobility is required. In Algiers, transport and urban planning have been the subject of many debates that have shown that the city suffers from several problems, in terms of transport, mobility, traffic and parking. This makes it a perfect example of a city affected by urban sprawl generating a series of other problems that come together to cause an imbalance in the layout of spaces. In attempting to address these problems in order, the first would be the increase in the various displacements due to the metropolisation and centralization of human activities. These displacements are not only in continuous increase but are experiencing a real imbalance where the quantity dominates on the quality, which leads to a remarkable saturation of the transport networks, and thus to a dense traffic notably during the peak hours. The purpose of this article is to demonstrate the importance of developing the most adequate operating policies for the various modes of transport that are the most appropriate in the capital city of Algiers, and to implement an investment program in the management of mobility in order to transform the city.
\end{abstract}

JOURNAL OF CONTEMPORARY URBAN AFFAIRS (2019), 3(1), 144-155. https://doi.org/10.25034/ijcua.2018.4711

www.ijcua.com

Copyright (C) 2018 Journal Of Contemporary Urban Affairs. All rights reserved.

\section{Introduction}

There can be no territories without connection, nor a city without system of transportation (Kaufmann, Yves Frrari, Dominique Joye, \& Fritz , 2003). Transport is a necessary condition for performing daily activities, however to satisfy these needs, a number of transportations is accomplished every day by individuals who leave their homes to go to different destinations, moving is a concept that improves over time through the multiplication of transportation motives leading to various forms of transport (Korkaz, 2013). This generated the need of concentration and convergence that gave birth to cities, where the reflection on the city became very tied to the reflection on

\footnotetext{
*Corresponding Authors:

University of Salah BOUBNIDER, Constantine, Algeria.

E-mail Address: ouafa.louafi@univ-constantine3.dz
} 
transport "... the transport networks in a city, are just like the skeleton and the circulatory system at the same time. In short, they constitute the main conditions for a city functioning" (Merlin, 1985).

In Algeria, with the acceleration of urbanization «As of January 1, 2016, the total resident population in Algeria reached 40.4 million inhabitantsı', transport has become a key sector for the economic and social development of the country. These recent years, traditional transport policies have an interest towards the demand for the private car, and have focused on assessing the role of urban transport and its contribution to urban integration and improvement of the quality of life in cities. Automobile-oriented development of city of Algiers with 1,254,553 cars $26.07 \%{ }^{2}$ of the national car fleet brought with it several problems in terms of transport, mobility, circulation and parking, as well as other problems related to pollution and urban sprawl. This is why the Algerian authorities take this term into consideration in the strategies for the implementation of the National Spatial Use Planning Scheme (NSPS) 2025. The studies for drawing up the four Master Plans for Urban Development Metropolitan Areas (MPDMA) Algiers, Oran, Annaba and Constantine, below the following objectives: setting off a major transport infrastructures, large structural facilities, and general orientations for protecting and enhancing the environment ${ }^{3}$.

The objective of this research is to demonstrate the importance of developing the operating policies of the various modes of transport most adequate in the Capital of Algiers, through the analysis of the different processes of transport planning and mobility management.

\section{Methodology of research}

This analytical research has allowed us to identify the major questions related to the problem of urban transport and its relation with the modernization and metropolisation of Algiers so that we can identify and understand the procedures and methods to follow, taking into account coordination between transportation and planning. Then, to better develop our research, we opted for a reading of the legislative framework for urban transport

(n.d.). Retrieved April 2018, from National Statistical Office: http://www.ons.dz/

${ }^{2}$ (n.d.). Retrieved 2018, from National Statistical Office: http://www.ons.dz/repartition-du-parcautomobile,211.html

${ }^{3}$ (n.d.). The implementation of the National Spatial Planning Scheme NSPS 2025 and urbanism documents dealing with the issue of mobility to arrive later in the presentation of the city of Algiers, type and mode of transport in the capital (case of study) and follow the strategies for modernization. Finally, we have the results of our analytical research that have demonstrated the absence of coordination between transport and urban planning and the inconsistency found in certain legislative and regulatory texts.

\section{Theoretical background}

\subsection{Urban policy and transport:}

According to (Merlin, 1993), the transport policy is "the set of guidelines determined by public authorities". The transport policy is the result of a process of regulation and control of transport reserves, to facilitate the efficient operation of economic, social and political aspects of a country (mobility of people and goods) to the lowest social cost and with total security.

The transport policy in Algeria has experienced several levels since independence, which the table below summarizes: see table ' 1 ', in Appendix 'A'.

\subsection{The institutional organization of transport 3.3. Planning in the transport sector}

Law N 01-20 of $12 / 12 / 2001$, relating to the planning and sustainable development of the territory defined the items and origins of the national planning policy and sustainable development via orientations, instruments of national policy and implementation of the national development plan of the territory, these instruments and tools form the interface of this policy, the following table summarizes the planning instruments in Algeria. See table '2\&3', in Appendix ' $A$ '.

\subsection{Existing laws and regulations in Algeria}

The laws and regulations in Algeria are reviewed at the General Secretariat of the Government, before they were proposed for discussion and adoption, and according to this the participation of the Ministry of Relations with Parliament should be noted, whose one of its missions is precisely to study and make a contribution to the projects initiated texts by other sectors. See table '4', Appendix 'A'.

\subsection{The report transport / town planning and town planning / Transport}

The relation between transport and town planning is a transitive relation. This gives some explanation by the impact of the decentering of equipment on the transport. More the poles 
of the various activities are far, more the distances traveled are long which involves an increase of car traffic on one hand. On the other hand, the location of jobs on the urban periphery and the development of automobile use often affect the rate of customers of public transport. As a result, the state of the road traffic gets worse every day.

\section{Case Study "The City of Algiers"}

The accelerated urbanization that knew the capital during this last decade provoked a series of problems that require an urban management of the space, the equipment, the structures and the functions today. This management requires the upgrade of the planning instruments to master the city and reach the purpose of the modernization and the metropolisation of the capital.

Among these problems; transportation that requires a comprehensive study. Following this, we tried to understand and target the problems of the articulation between urban planning and the transport system in Algiers.

\subsection{Presentation of Algiers}

Algiers, capital of the country occupying a strategic position in the Mediterranean Rim and the gate of the African continent which gives it an important economic and political influences.

Considered to be the most populous province (Wilaya) of Algeria with 2,988,1604 inhabitants and a density of 3,691 inhabitants / $\mathrm{km}^{2}$ cover an area of $804.74 \mathrm{~km}^{2}$, it is the smallest Algerian Wilayas. It is composed of thirteen "13" dairas, each comprising several communes, for a total of fifty-seven municipalities.

\section{- Geographical situation}

- Evolution of the population

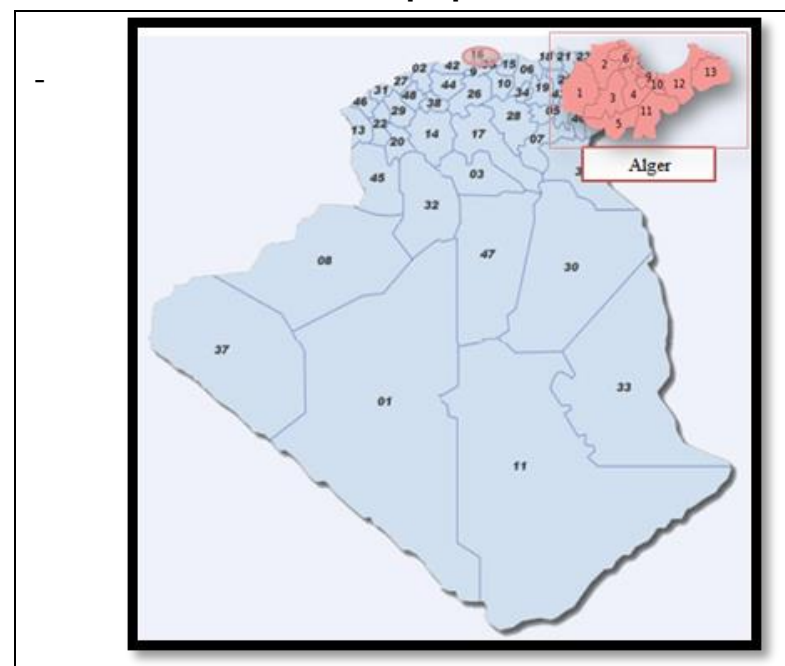

Figure 1. Situation of Wilaya of ALGIERS (treatment Source: Google Image
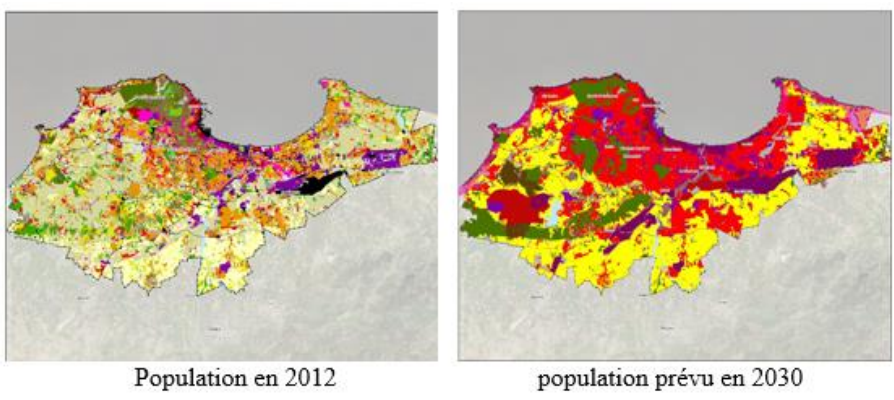

Figure 2. Evolution of the population. Source: TSO EGIS

The population is the intervening variable in any projections, also considered as a source of tension and imbalance of any territorial organizational policy.

\subsection{Urban transport network in Algiers}

Transport is considered a motive movement (work, purchase, leisure ... etc.) of a person made for a certain reason, between an origin and a destination, using one or more modes of transport, according to a route and for a specific duration (MINISTRY OF TRANSPORT OF QUEBEC). Among the modes of transport and the means of transport in Algiers, we quote:

\section{- Road transport}

Either individual (on foot, by vehicle, or by motorcycle) or common (bus, taxi,). The network consists of an entanglement of several lines spreading on different axes; they collect a number of vehicles that exceed 143,000 vehicles ${ }^{5}$.

$$
\begin{array}{ll}
\text { - } & \text { NH National Highway: } 542 \mathrm{Km} \\
\text { - } & \text { OTR office town Roads: } 660 \mathrm{Km} \\
\text { - } & \text { LR Local roads: } 794 \mathrm{Km}
\end{array}
$$

- Construction of 1,250 engineering structures (new construction, rehabilitation and maintenance) and 37 hoppers.

Traffic at the two most important roads in the country, NH 4 and NH 5 between Oran and Constantine, passing through Algiers, is very important, ranging from 12,000 to 25,000 vehicles per hour depending on the section. At the approach of the Wilaya of Algiers, traffic easily reaches 50,000 vehicles per hour. This saturation will require a great development in the railway suburbs. (CHELLA , 2014)

${ }^{4}$ (NOS, 2008)

5 (NOS, 2008) 


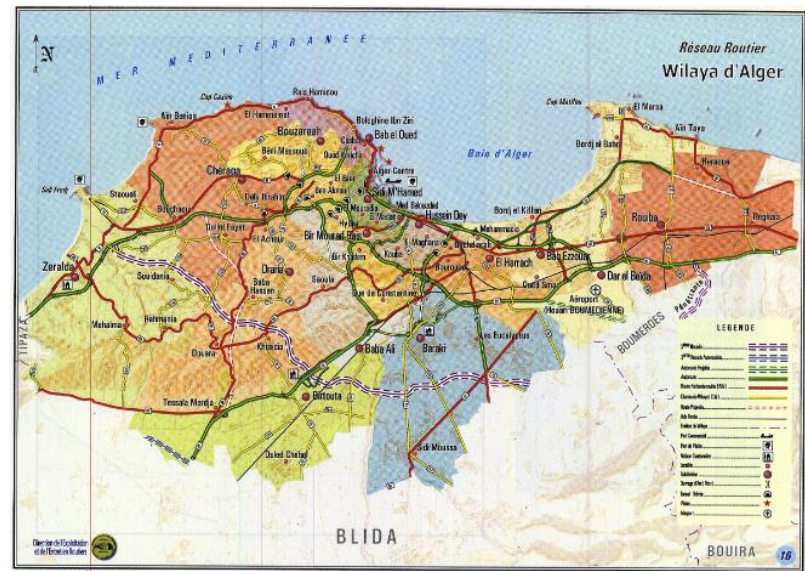

Figure 3. Road transport network in Algiers. Source: Road Operations and Maintenance Branch

\section{- Rail transport}

The capital Algiers is connected to the national rail transport network by lines that run along the city to other Wilaya through a network comprising (tracks, stations, tunnels and bridges).

\section{- Air transport}

Algiers has air transport services which includes a national and international airport whose characteristics are classified in table 5, Appendix ' $A$ ':

\section{- Maritime transport}

The port of Algiers gives it the advantage of a gateway to Africa and makes the city a crossing point for human flows and goods traded on the world market, we quote:
03 headlights
01 commercial port
03 fishing ports

\subsection{Future of transport infrastructure in Algiers}

The modernization of the capital Algiers requires the creation of infrastructure networks and hubs to better structure the city, and although the city has an important infrastructure, it remains insufficient comparing to the rampant urbanization that know the capital. To this end, several projects planned for the year 2025 according to the strategic plan of Algiers, that refers to the lengthening of traffic congestion during rush hours, the facilitation of parking in the heart of the city. Among these projects; six road infrastructure projects, five local road projects, three interchanges, three new bus stations, eight multi-storey car parks and three car parks, two gondolas and the completion of the metro and tram. (OUAZEN, 2012)

\subsection{Urban planning instruments and transport in the city of Algiers}

Table ' 6 ', in Appendix 'A', illustrate the urban planning instruments and transportation in the city of Algiers.

\section{Results}

Through the analysis of the various instruments of the planning and the situation of the transport sector in the city of Algiers, some deficiencies and shortcomings were observed, especially the inconsistency and the noncoordination between these two sectors (Planning and transport), for these reasons we have established some sources of malfunction:

- The chronological non-respect of different instruments of urban planning elaboration, and the absence of the complementary relation between the different urban planning instruments, that is shown through the absence of coordination and control between these different instruments.

- Marginalization of the transport sector in the planning instruments on which programming instruments are based for, this is marked by; the absence of a long-term vision that includes the issue of transport with all these dimensions, the incompetence of actors and companies to manage the transport and planning policy and finally the non-respect of the orientations proposed by urban policy.

Consistent legislative and regulatory framework Despite the rich content of the existing legislative framework, the absence of a strategy of coordination of the transport and planning imposes dysfunctions of the city.

- The texts relating to planning and urban planning indicate that the mission of urban plans is essentially limited to urban planning aspects while the dimension of urban transport is completely failed. In addition, Law 90.29 on planning and urban planning did not emphasize the procedure for implementing coordination of planning and transport.

- The 2001 law on the orientation and organization of terrestrial transport imposes in its articles 40-41-42-43 the obligation to integrate transport planes into documents.

\section{Discussions}

Planning a type of transport requires a very deep analysis of many factors including space, time, money, quality of service and the nuisance it generates (noise, pollution, congestion ...). Through this analysis, we've reached to a synthesis that would allow us to 
operationalize the coordination urban planning and urban transport for a harmonious development of the city of Algiers.

- $\quad$ Think about checking, controlling and restoring the legislative framework that affects the planning and transport sector to ensure better coordination between the two sectors, control of urban sprawl and modal shift towards public transport.

- $\quad$ Articulate between the fields and scales of planning (spatial planning, urban plan and transport plan)

- Deepen the communication between the public authorities, and to create an interface of local debate within the agglomerations (governance).

- Reform and improve legislation and regulations, while facilitating its reading and its application, and involve its importance in the field of urban planning and construction, particularly in the training curriculum of the architect, engineer, and the administrator.

- Make a comprehensive review of legislation and regulations related to urban planning and transportation to distinguish existing inconsistencies.

- Integration of the concept of mobility in MPUP/POG urban planning documents

- The programming of the various projects at central and local level, with a view to ensuring better harmonization and coordination between the different actors.

\section{Conclusions}

If the situation of transport and mobility networks in the city of Algiers nowadays may reveal to us something, it would be the standpoint towards the implementation of a better management of transport, which reveals the question of the coordination between transport and urban planning instruments, which we have emphasized in our article. And this, in order to guarantee a more favorable quality of life. "The art of developing cities today depends on the ability to control flows and circulations, to organize the mobility of people and goods" (Wachter, 2003). Therefore to better understand and regulate these problems raised by transport, the institutions, administrations and local authorities who are responsible for managing cities, should consider establishing an urban transport plan that will constitute an integral part of the urban master plan and which will be covered by the challenge of providing a perfect coherence with urban development plans. Despite the setting up of the legislative and regulatory framework, and the efforts of direction that have been made for the benefit of transport in the city, the imbalance of the urban framework and the inefficiency of the transport, would be nothing comparing to what the fact of dysfunction between urban planning and urban transport can generate, which is in fact due to the weak managerial capacity and the insufficiency of the actors concerned by this fact and who are in charge of the establishment of the various instruments as well as by the phase shift that occurred during the development of these.

\section{Abbreviations}

MCET Ministry of Civil Engineering and Transport

MHU Ministry of Housing and Urbanism

DWT Direction of province (Wilaya) Transport

DCE Directions of Civil Engineering

U.T.O.A Urban transport organizing authority

NSPS National Spatial Planning Scheme

RSPS Regional Spatial Planning Scheme

MPDMA Master Plan for the Development of

Metropolitan Areas

ASMP Airport Sector Master Plan

TODP Town Office Development Plan

MP Master Plan

MPUP Master Plan of Urban Planning

POG Plan of Occupation of ground

MDP Municipality Development Plan

UTP Urban Travel Plan

GCPH General Census of Population and

Housing

NH National Highway.

OTR office town Roads

LR Local roads

PT Public Transport.

PTC Passenger Transport Center

PTW West Passenger Transportation

PTSO South West passenger transportation

PTSE Passenger Transport South East

OJ Official Journal

TSO Technical Study Office

ASROUT Establishment of Maintenance of Road and Sanitation of the office town of Algiers

DUTRT Direction of urban transport and road traffic (DTUCR)

UTSO Urban Transport Studies Office (BETUR)

TMUTC Traffic Management and Urban

Transport Company (EGCTU)

NPSF National Pension and Social Security Fund (CNRPS)

NTCE National technical control establishment

(ENACTA)

NCSARUP National Center for Studies and

Applied Research in Urban Planning (CNERU)

DUPCH Direction of Urban Planning,

Construction and Housing (DUCH)

AUSPTE Algiers Urban and Suburban Public Transport Establishment (ETUSA) 
EMA Algiers Metro Company

DTCT Direction of Trams and Cable Transport (DPTTC)

NRTC National Railway Transport Company (SNTF)

\section{Acknowledgements}

This research did not receive any specific grant from funding agencies in the public, commercial, or not-for-profit sectors.

\section{Conflict of interests}

The author declares no conflict of interest.

\section{References}

Baiteche, H. (1999). Identification des causes de défaillance des instruments d'urbanisme à savoir PUD et PDAU, Cas d'études ville de Bejaia. [Identification of causes of failure of urban planning instruments namely MPUP and POG, case of study city of Bejaia.], Alger, Algérie: Ecole polytechnique d'architecture et d'urbanisme. Récupéré sur http://www.epau-

alger.edu.dz/index.php/bibliotheque/catal ogue/memoires-de-magistere

Baouni, T. (2003, Décembre). Aménagement urbain et développement durable. [Mobility, Urban Planning and Sustainable Development.], Alger, Algérie: Ecole polytechnique d'architecture et d'urbanisme. www.univ-bejaia.dz

Baouni, T. (2008). Quelle stratégie pour les villes Algériennes. E.g : [Urban transport: "What strategies for Algerian cities], Colloque international sur l'aménagement urbain et développement durable. Oran. https://search.openedition.org

Baouni, T. (2009). Le transport dans les stratégies de la planification urbaine de l'agglomération d'Alger. E.g: [Transport in the strategies of urban planning of the agglomeration of Algiers.], (44-45/2009), pp. 75-95. Récupéré sur https://journals.openedition.org/insaniyat/4 81

Baouni, T. (2010). Les dysfonctionnement de la plaification urbaine et des transports urbains dans les villes Algériennes. E.g: [Malfunctions urban planning and urban transport in Algerian cities.], Alger, Algérie: Ecole Polytechnique d'Architecture et d'Urbanisme (EPAU). Récupéré sur http://www.codatu.org/wpcontent/uploads/Les-dysfonctionnementsde-la-planification-urbaine-et-destransports-urbains-dans-les-villesAlg\%C3\%A9riennes-Tahar-BAOUNI.pdf
Baouni, T., \& BERCHACHE, R. (2011). Intermodalité et développement urbain dans l'aglomeration d'Alger, défis, enjeux et perspectives. E.g: [Intermodality and urban development in the Algiers agglomeration, challenges, issues and perspectives.], (97/2011), p. 93. Récupéré sur file:///C:/Users/kj/Downloads/125550342040-1-SM.pdf

Benamara, S. (2012, avril 24). Territoire communal en Algérie entre développement urbain et textes juridique, Cas d'étude; commune de corso. E.g: [Municipal territory in Algeria between urban development and legal texts, case study; municipality of Corso.], Bejaia, Algérie: Université de Béjaia. https://ruralm.hypotheses.org/1065

Chella, T. $(2014,11$ 22). Maitrise de la gestion du transport de marchandises en ville et son impact régional, Cas d'Alger . E.g: [Ability to manage the transport of goods in urban areas and their regional impact, Case of Algiers.], Alger, Algérie: Université des sciences et de la technologie HouariBoumédiène (USTHB). https://docplayer.fr/76484549-Cahiersgeographiques-de--ovest-n-le-tramway-a-lepreuve-des-mobilites-dans-les-villes-

algeriennes-et-du-bassinmediterraneen.html

Deligny, J.-I., \& Gressier, C. (1978). Mieux ce déplacer dans la ville. E.g: [Better move in your city.], Paris: Moniteur. https://www.abebooks.com/booksearch/title/mieux-d\%E9placerville/author/deligny-gressier/

Harouche, K. (1987). Les transports urbains dans l'agglomération d'Alger. E.g: [Urban transport in the Algiers agglomeration.], (L'Harmattan, Éd.) Paris.

Journal officiel. (s.d.). Récupéré sur https://www.joradp.dz/HAR/Index.html

Kaufmann, V., Yves, F., Dominique, J., \& Fritz, S. (2003). Coordonner transport et urbanisme. E.g: [Coordinate transportation and urban planning.], (P. P. (PPUR), Éd.) https://www.eyrolles.com/BTP/Livre/coordo nner-transports-et-urbanisme9782880745189

La loi 01-13 du 17 août 2001 portant orientation et organisation des transports terrestres. (2001, Août 17). E.g: [Law 01-13 of 17 August 2001 on the orientation and organization of land transport. (2001).]. http://www.elmouwatin.dz/IMG/pdf/loi_0113.pdf 
La loi 90-29 du 1990 relative à l'aménagement et l'urbanisme. (1990). E.g: [Law 90-29 of 1990 on planning and urban planning. (1990).].

https://www.ecolex.org/details/legislation/l oi-no-90-29-relative-a-lamenagement-et-

lurbanisme-lex-faoc004594/

Madani, S. Z., \& Tabti-talamali, A. (2009). La mobilité urbaine dans l'agglomération d'Alger, évolution et perspectives. E.g: [Urban mobility in the agglomeration of Algiers: evolution and perspectives.], Alger. Récupéré sur https://planbleu.org/sites/default/files/publi cations/mobilite_urbaine_alger_fr.pdf

Meghitif, S. (2008, Septembre). Conditions d'articulation urbanisme-transport, cas de l'agglomérationd'Alger. E.g: [conditions of articulation between urban planning and transport, Case of the agglomeration of Algiers.], Université de Montréal., Récupéré sur

https://papyrus.bib.umontreal.ca/xmlui/bits tream/handle/1866/2699/Meguittif_Salim_2 008_M\%C3\%A9moire.pdf? sequence=3\&isAll owed =y

Merlin, P. (1993). Géographie des Transports. E.g: [Geography of Transport.], Annales de géographie. Récupéré sur https://www.persee.fr/doc/geo_00034010_1993_num_102_571_21152_†1_0307_00 00_2

Merlin, P. (1985). La planification des transports urbains. E.g: [Urban transport planning.],Paris: Revue géographique des Pyrénées et du Sud-Ouest. Sud-Ouest Européen . Récupéré sur https://www.persee.fr/doc/rgpso_00353221_1985_num_56_1_3004_†1_0135_0000_2

Neggaz, K. (2001). Interaction transport urbainoccupation du sol, cas de l'agglomération
d'Alger. E.g: [Interaction urbain transport and land occupation, Case of 'agglomeration of Algiers.], Alger, Algérie: Ecole polythechnique d'architecture et d'urbanisme. Récupéré sur

http://www.epau-

alger.edu.dz/index.php/post-

graduation/formation/troisieme-cycledoctorat/14-bibliotheque

Office National des Statistiques en Algérie. (n.d.). Consulté le 2018, sur http://www.ons.dz/REPARTITION-DU-PARCAUTOMOBILE, $211 . \mathrm{html}$

Office National des Statistiques en Algérie. (n.d.). Récupéré sur Office National des Statistiques en Algérie: http://www.ons.dz/

Official website of the Ministry of Transport and civil engineering. (n.d.). Récupéré sur Official website of the Ministry of Transport and civil engineering: http://www.mtp.gov.dz/fr/

Problématiques du transport urbain et de la mobilité urbaine durable en Algérie, les défis et les solutions. E.g: [Urban Transport Issues and Sustainable Urban Mobility in Algeria, Challenges and Solutions.), (14 \& 15 Octobre 2014). Batna. Récupéré sur http://lab.univ-

batna.dz/LMTL25/index.php/colloqueinternational-problematiques-du-transporturbain-et-de-la-mobilite-urbaine-durableen-algerie-les-defis-et-les-solutions .

Varlet, J., \& Zembri, P. (2010). Les transports dans le monde d'aujourd'hui. E.g: [Transport in the world today.], Atlas des transports. http://www.col-bouxwiller.acstrasbourg.fr/peda/histgeo/avril2012/transp orts2.pdf

\section{Appendix A: Tables}

Table 1. Periods of transport policy in Algeria

The 1962-1967 period the Monopoly of the National Transport Office

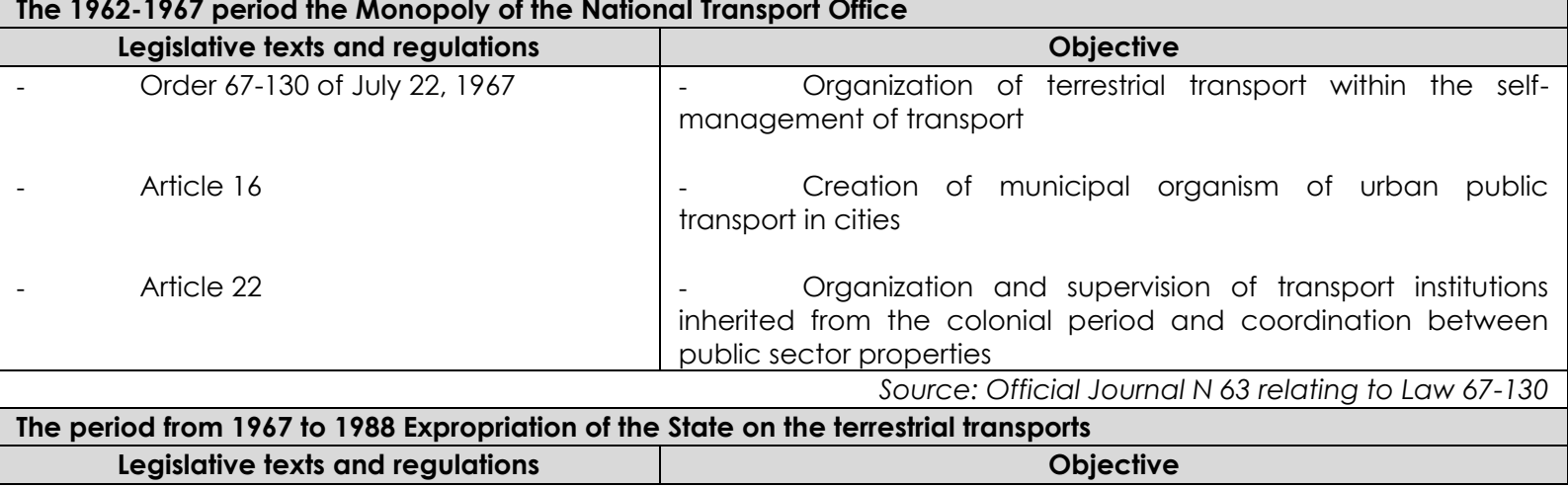




\begin{tabular}{|c|c|}
\hline Order 71-73 du 17 November 1971 & $\begin{array}{l}\text { - Absence of monopoly private sector of SNTV although } \\
\text { the existence of a legal framework that allows this activity. }\end{array}$ \\
\hline & Source : Official Journal N 97 relating to the order7 1-73 \\
\hline Decree 81-375 of December 26, 1981 & $\begin{array}{ll}\text { - } & \text { The attribution of the municipality and the Town Office } \\
\text { - } & \text { Absence of the private sector }\end{array}$ \\
\hline \multicolumn{2}{|c|}{ Source : Official Journal N 52 relating to decree 81-375 } \\
\hline Decree $83-306$ of 07 may 1983 & $\begin{array}{l}\text { - Ending the centralization and distribution of public } \\
\text { company passenger in: TVC center, TVO West. TVSO South West. } \\
\text { TVO East and TVSE South-East. }\end{array}$ \\
\hline \multicolumn{2}{|r|}{ Source : Official Journal N 19 relating to decree 83-306 } \\
\hline \multirow[t]{2}{*}{ Interministerial Order 20 May 1987} & Integration of the private sector in the transport sector \\
\hline & Source: Official Journal N 21 relating to the Interministerial Order \\
\hline \multicolumn{2}{|c|}{ The period from 1988-2001: opening of the road transport market } \\
\hline Legislative texts and regulations & Objective \\
\hline \multirow[t]{2}{*}{ Executive Order 88-01 of January 12, 1988} & $\begin{array}{l}\text { - Canceling of the state and a strong emergence of the } \\
\text { private sector } \\
-\quad \text { Abandonment of institutions by the State } \\
-\quad \text { Improving the efficiency and productivity of } \\
\text { commercial institutions }\end{array}$ \\
\hline & Source: Official Journal N 02 relating to the Executive Order 88-01 \\
\hline \multirow[t]{2}{*}{ Law 88-17 of May 10, 1988} & - Private sector development \\
\hline & Source: Official Journal N 19 relating to the Executive Order 88-17 \\
\hline \multirow[t]{2}{*}{$\begin{array}{l}\text { Executive Decree N } 90-381 \text { of } 24 \text { November } \\
1990\end{array}$} & $\begin{array}{l}\text { Improved profitability and efficiency of institutions to } \\
\text { make them more productive in accordance with the } \\
\text { commercial code }\end{array}$ \\
\hline & Source: Official Journal N 51 relating to the Executive Order 90-381 \\
\hline \multirow[t]{2}{*}{ Executive Decree N 91-195 of 01 June 1991} & $\begin{array}{l}\text { Fix the general conditions for the exercise of terrestrial } \\
\text { transport activities within the framework of Law N 88-17 of May } \\
10,1988, \text { Mentioned above. }\end{array}$ \\
\hline & Source: Official Journal N 27 relating to the Executive Order 91-195 \\
\hline \multicolumn{2}{|l|}{ The period from 2001 to 2012} \\
\hline \multirow{2}{*}{$\begin{array}{c}\text { Legislative texts and regulations } \\
\text { Executive Decree N 03-261 of July 23, } 2003\end{array}$} & Objectives \\
\hline & $\begin{array}{l}\text { Composition, allocation and operation of the National } \\
\text { terrestrial Transport Council, the Interministerial Technical } \\
\text { Committee for the Transport of Dangerous Material and the } \\
\text { Administrative Penalties Commission of Wilaya (Province) } \\
\text { Source: Official Journal N46 }\end{array}$ \\
\hline $\begin{array}{l}\text { Executive Decree N 04-416 of December 20, } \\
2004\end{array}$ & $\begin{array}{c}\text { Determination of the procedures for drawing up and } \\
\text { implementing terrestrial transport plans for people } \\
\text { Source: Official Journal N } 62\end{array}$ \\
\hline Executive Decree N 09-89 of February 17, 2009 & $\begin{array}{l}\text { Determination of the operating methods of the } \\
\text { account of special assignment } \mathrm{N} 302-125 \text { entitled: special fund } \\
\text { for the development of public transport } \\
\text { Source : Official Journal } N^{\circ} 12\end{array}$ \\
\hline $\begin{array}{l}\text { Executive Decree n10-91 Law N 11-09 of June } \\
5,2001 \text { amending and supplementing Law N } \\
01-13 \text { of August } 7,2001\end{array}$ & $\begin{array}{l}\text { Orientation and organization of terrestrial transport; } \\
\text { public transport, own transport, operation, combined intermodal } \\
\text { transport, vehicle, rail transport, guide transport of persons, road } \\
\text { transport of persons and goods. }\end{array}$ \\
\hline Executive Decree N 12-109 of March 06, 2012 & $\begin{array}{l}\text { Organization of the functioning and missions of the } \\
\text { urban transport organizing authority. } \\
\text { - Adoption of A.O.T.U of certain Wilaya (province) } \\
\text { Source: Official Journal N } 15 \text { relating to Executive Decree 12-109 }\end{array}$ \\
\hline Executive Decree N 12-190 of April 25, 2012 & $\begin{array}{l}\text { Creation of the authorities organizing urban transport of } \\
\text { some Wilaya (province) including Algiers, Oran, Constantine, } \\
\text { Annaba, Setif, Batna, Sidi bel abbots, Mostaganem, and } \\
\text { Ouargla. } \\
\text { Source: Official Journal N } 25 \text { relating to Executive Decree 12-190 }\end{array}$ \\
\hline Executive Decree N 12-230 of May 24, 2012 & $\begin{array}{l}\text { Regulation of taxi transportation in } 03 \text { forms: } \\
\text { - Individual taxi services } \\
\text { - Urban Collective Tax Services } \\
\text { - Non Urban Collective Taxi Services } \\
\text { Source : Official Journal N } 33 \text { relating to Executive Decree 12-230 }\end{array}$ \\
\hline
\end{tabular}

Source: (Official Journal, n.d.)

(Author treatment) 
Table 2. Synthesis of transport organizations and these responsibilities

\begin{tabular}{|c|c|c|}
\hline \multicolumn{2}{|c|}{ Institutional organization of transport } & \multirow{2}{*}{ Responsibilities } \\
\hline Organization or under guardianship & Office Town and regional institutions & \\
\hline $\begin{array}{l}\text { MCET; Ministry of Civil Engineering and Transport (French: } \\
\text { MTPT ministère des transports et des travaux publics) }\end{array}$ & & Transport policy \\
\hline $\begin{array}{ll}- & \text { MCET; Ministry of Civil Engineering and Transport (Fr: } \\
\text { MTPT) } & \\
- & \text { DTT; direction of terresterial transport }\end{array}$ & $\begin{array}{l}\text { DWT; Direction of ( province } \\
\text { Transport (Fr: Direction des transports des } \\
\text { wilayas DTW) }\end{array}$ & $\begin{array}{l}\text { Organization of public } \\
\text { transport }\end{array}$ \\
\hline DTT; direction of terrestrial transport & $\begin{array}{l}\text { DWT; Direction of province } \\
\text { Transport (Fr: DTW) }\end{array}$ & $\begin{array}{l}\text { Regulation of terrestrial } \\
\text { transport }\end{array}$ \\
\hline MCET; Ministry of Civil Engineering and Transport (Fr: & $\begin{array}{l}\text { DCET; } \\
\text { Engineering (Fr: Direction of }\end{array}$ & $\begin{array}{lr}\text { National and } & \text { Regional } \\
\text { Road } & \text { network: } \\
\text { Construction } & \text { and } \\
\text { Maintenance } & \\
\end{array}$ \\
\hline \multicolumn{2}{|c|}{$\begin{array}{l}\text { DCET; Direction of Civil Engineering (Fr: DTP) } \\
\text { Establishment of Maintenance of Road and Sanitation of the province of Algiers (Fr: ASROUT) }\end{array}$} & $\begin{array}{l}\text { Urban roads. Construction } \\
\text { and maintenance. }\end{array}$ \\
\hline \multicolumn{2}{|l|}{ DWT; Direction of province Transport (Fr: DTW) } & $\begin{array}{l}\text { Transportation } \\
\text { authorizations, driver's } \\
\text { license, driving school }\end{array}$ \\
\hline $\begin{array}{l}\text { DUTRT ; Direction of urban transport and road traffic (Fr: } \\
\text { direction des transports urbain et de la circulation routière DTUCR) } \\
\text { - } \quad \text { UTSO ; Urban Transport Studies Office (Fr : BureaU Des } \\
\text { Etudes des transports urbains BETUR) }\end{array}$ & $\begin{array}{l}\text { DWT; Direction of province } \\
\text { Transport (Fr: DTW) }\end{array}$ & Transport study \\
\hline 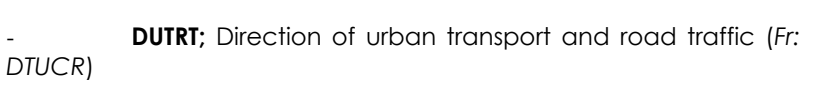 & $\begin{array}{l}\text { TMUTC Traffic Management and Urban } \\
\text { Transport Company (EGCTU) } \\
\text { Policy }\end{array}$ & Traffic Management \\
\hline $\begin{array}{l}\text { - DUTRT; Direction of urban transport and road traffic (Fr: } \\
\text { DTUCR) } \\
-\quad \text { NPSF ; National Pension and Social Security Fund (Fr : } \\
\text { Caisse nationale de retraite et de prévoyance sociale CNRPS) } \\
\text { NTCE ; National technical control establishment (Fr: } \\
\text { Etablissement National de Contrôle Technique Automobile } \\
\text { ENACTA) } \\
- \\
\text { GENDARMERIE }\end{array}$ & $\begin{array}{l}\text { Committee of Traffic and Road } \\
\text { Police }\end{array}$ & Road safety \\
\hline $\begin{array}{l}\text { - MHU Ministry of Housing and Urban Planning (Fr: Ministère } \\
\text { d'Habitat et d'Urbanisme MHU) } \\
\text { - NCSARUP National Center for Studies and Applied } \\
\text { Research in Urban Planning (Fr: Centre National d'Etudes et de } \\
\text { Recherche appliquée en Urbanisme CNERU) }\end{array}$ & $\begin{array}{l}\text { - DCUP Direction of Construction } \\
\text { and Urban Planning (Fr : Direction } \\
\text { d'urbanisme et de construction DUC) } \\
\text { - } \quad \text { URBANIS }\end{array}$ & Urban planning \\
\hline $\begin{array}{l}\text { AUSPTE Algiers Urban and Suburban Public Transport } \\
\text { Establishment (Fr : Etablissement public de transport urbain et } \\
\text { suburbain d'Alger ETUSA) } \\
\text { - } \\
\text { TRANSUB }\end{array}$ & $\begin{array}{l}\text { Private operators } \\
\text { Collectives taxis }\end{array}$ & $\begin{array}{l}\text { Exploitation of urban } \\
\text { public transport }\end{array}$ \\
\hline EMA Algiers Metro company & & $\begin{array}{l}\text { Realization of the Algiers } \\
\text { metro }\end{array}$ \\
\hline DTCT Direction of Trams and Cable Transport (Fr: DPTTC) & & $\begin{array}{l}\text { Realization of the } \\
\text { tramway of Algiers }\end{array}$ \\
\hline NRTC National Railway Transport Company (Fr: SNTF) & & $\begin{array}{l}\text { Electrification of suburbs } \\
\text { trains }\end{array}$ \\
\hline $\begin{array}{l}\text { AUSPTE Algiers Urban and Suburban Public Transport } \\
\text { Establishment (Fr: ETUSA) } \\
-\quad \text { DTCT Direction of Trams and Cable Transport (Fr: DPTC) } \\
\end{array}$ & & Cable \\
\hline \multirow[t]{2}{*}{$\begin{array}{l}\text { AUSPTE Algiers Urban and Suburban Public Transport } \\
\text { Establishment (Fr: ETUSA) }\end{array}$} & $\begin{array}{l}\text { DWT Direction of province } \\
\text { Transport (Fr: DTW) } \\
\text { Private operators }\end{array}$ & Specialized transportation \\
\hline & $\begin{array}{l}\text { DWT Direction of province } \\
\text { Transport (Fr: DTW) } \\
-\quad \text { Private operators } \\
\end{array}$ & Taxis \\
\hline
\end{tabular}

Source: Study of the urban transport plan and the traffic plan of the agglomeration of Algiers (Update author 2018) 
Table 3. Urban and Regional Planning System in Algeria

\begin{tabular}{|c|c|c|c|c|}
\hline Laws & $\begin{array}{c}\text { The law of Spatial } \\
\text { Planning }\end{array}$ & $\begin{array}{c}\text { The law of planning and } \\
\text { urban planning }\end{array}$ & Town Office Code & Communal code \\
\hline instruments & $\begin{array}{ll}- & \text { NSPS } \\
- & \text { MPDMA }\end{array}$ & $\begin{array}{ll}- & \text { MPUP } \\
- & \text { POG }\end{array}$ & TODP & MDP \\
\hline Objectives & $\begin{array}{l}\text { - Regional } \\
\text { balance } \\
-\quad \text { Inter-sectoral } \\
\text { and inter-regional } \\
\text { coordination. } \\
\text { - Optimization } \\
\text { resources. }\end{array}$ & $\begin{array}{l}\text { - } \quad \text { Orientation of the } \\
\text { development } \\
-\quad \quad \text { Rationalization of } \\
\text { the use of ground }\end{array}$ & $\begin{array}{l}\text { Development of } \\
\text { the province (Wilaya). }\end{array}$ & $\begin{array}{l}\text { Development } \\
\text { of the municipality. }\end{array}$ \\
\hline Contents & $\begin{array}{ll}- & \text { Schema } \\
- & \text { Orientation }\end{array}$ & $\begin{array}{ll}- & \text { Development } \\
- & \text { Regulation. } \\
- & \text { Graphic } \\
\text { document }\end{array}$ & $\begin{array}{l}\text { Vocation and } \\
\text { function of the province } \\
\text { (Wilaya). }\end{array}$ & $\begin{array}{l}\text { Vocation } \\
\text { and function of the } \\
\text { municipality }\end{array}$ \\
\hline The criteria & $\begin{array}{l}-\quad \text { Sectoral } \\
\text { policies (hydraulics, } \\
\text { transport and tourism) } \\
-\quad \quad \text { Resources, } \\
\text { natural human }\end{array}$ & $\begin{array}{l}\text { - Opposability to } \\
\text { third party } \\
-\quad \text { Population social } \\
\text { economy } \\
-\quad \text { Urban } \\
\text { composition } \\
-\quad \text { Architecture. }\end{array}$ & $\begin{array}{l}\text { - General } \\
\text { directions of the NSPS, the } \\
\text { RSPS and the law on the } \\
\text { development }\end{array}$ & $\begin{array}{l}\text { - General } \\
\text { directions of the NSPS, } \\
\text { the RSPS and the } \\
\text { TODP. }\end{array}$ \\
\hline The scales & National Regional & Communal & province (Wilaya) & Communal \\
\hline Elaboration & $\begin{array}{l}\text { - Structures } \\
\text { responsible for territorial } \\
\text { planning. }\end{array}$ & $\begin{array}{ll}- & \text { Province (Wilaya) } \\
- & \text { Wali (APW) } \\
- & \text { Urban planning } \\
\text { ministers } & \\
- & \text { local } \\
\text { communities }\end{array}$ & $\begin{array}{ll}- & \text { assembled } \\
\text { province } & \text { (Wilaya) people. } \\
- & \text { Wali. }\end{array}$ & $\begin{array}{l}\text { assembled } \\
\text { communal people }\end{array}$ \\
\hline Approval & - & $\begin{array}{ll}- & \text { province (Wilaya) } \\
\text {-Wali } & \\
- & \text { Urban planning } \\
\text { ministers } & \text { local } \\
- & \text { communities }\end{array}$ & $\begin{array}{ll}- & \text { assembled } \\
\text { province } & \text { (Wilaya) people. } \\
- & \text { Wali. }\end{array}$ & $\begin{array}{l}\text { assembled communal } \\
\text { people }\end{array}$ \\
\hline Management & Sector & Communal & (Wilaya) & Communal \\
\hline
\end{tabular}

Source: (BAOUNI, Malfunctions urban planning and urban transport in Algerian cities)

Table 4. Existing Legislative and Regulatory Texts in Algeria

\begin{tabular}{|c|c|}
\hline Legislative text & Definition \\
\hline Order & $\begin{array}{l}\text { Enacted by the President of the Republic between the two parliamentary sessions of the } \\
\text { spring and autumn. In most of the cases, this order, once the parliamentary session opens, } \\
\text { passed by the parliament with its two chambers, and is approved in the form of "law". }\end{array}$ \\
\hline Law & $\begin{array}{l}\text { "The law in the formal sense is the law voted by the parliament and enacted by the } \\
\text { president of the republic". The proposed legislation, to be admissible, are filed by twenty } \\
\text { (20) deputies. The draft laws presented by the cabinet after consulting the Council of State } \\
\text { then submitted by the first Minister on the National Popular office of the assembly. }\end{array}$ \\
\hline Presidential Decree & $\begin{array}{l}\text { According to the article } 77 \text { of the presidential, decree } N 96-438 \text { the presidential decree is } \\
\text { signed by the president of the republic on the report of the Secretary concerned by the } \\
\text { device. }\end{array}$ \\
\hline Legislative Decree & $\begin{array}{l}\text { This disposal has been put in place precisely during the period of application of the } \\
\text { platform national consensus on the transitional period, and this, following the judgment of } \\
\text { electoral process in } 1922 \text { regarding legislative decree specifies how enactment of this type } \\
\text { of text. }\end{array}$ \\
\hline Executive Decree & $\begin{array}{l}\text { Was signed by the chef of the government before the constitutional revision of November } \\
2008 \text { and is signed by the first minister after the revision of the constitution and this, on } \\
\text { report of the minister concerned after approval of the president of the republic. }\end{array}$ \\
\hline Decree & $\begin{array}{l}\text { This disposal has been abandoned for some years before, there has been promulgation of } \\
\text { texts by decree signed either by the President of the Republic or the first Minister. }\end{array}$ \\
\hline $\begin{array}{l}\text { Interministeril } \\
\text { Instruction }\end{array}$ & $\begin{array}{l}\text { Instruction concerning a particular domain, with interference from several different sectors, } \\
\text { to be published in the Official Journal, and to be signed } \\
\text { Jointly by two or more ministers. }\end{array}$ \\
\hline Ministerial Instruction & Instruction concerning a particular domain, with the intervention of a single sector to be \\
\hline
\end{tabular}




\begin{tabular}{|c|l|}
\hline & published in the official journal, which must be signed by the minister concerned. \\
\hline & Being signed by several different levels of competence under: \\
Stopped & - Minister \\
& - Two or more ministers \\
& - Wali \\
& - President of the Municipal People's Assembly.
\end{tabular}

Source: (BENAMARA, Municipal territory in Algeria between urban development and legal texts, case study; municipality of Corso, 2012).

Table 5. Characteristics of Algiers Airport

Source: (ASMP) 2005-2025

\begin{tabular}{|c|c|c|c|c|c|c|c|c|c|c|c|c|c|c|c|}
\hline \multirow[b]{2}{*}{ Aerodrome } & \multicolumn{3}{|c|}{ Taxiway } & \multicolumn{3}{|c|}{ Strops } & \multicolumn{3}{|c|}{ Parking } & \multicolumn{3}{|c|}{ Main Track } & \multicolumn{3}{|c|}{ Secondary Track } \\
\hline & $\frac{0}{\mathbf{z}}$ & $\begin{array}{l}\text { ס } \\
\text { 옹 }\end{array}$ & ס் & $\frac{0}{2}$ & $\begin{array}{l}\text { D } \\
\text { 오 }\end{array}$ & कृ & $\begin{array}{l}\overline{\grave{0}} \\
\frac{0}{0} \\
\frac{0}{0} \\
\mathbf{z}\end{array}$ & : & ర్ర & 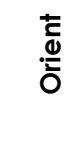 & 뭄 & ర্் & 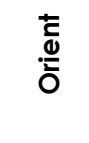 & o & రृ \\
\hline \multirow{3}{*}{$\begin{array}{l}\text { Algiers/ Houari } \\
\text { Boumédiénne }\end{array}$} & \multirow{3}{*}{2} & $\begin{array}{l}35 \\
00 \\
\end{array}$ & \multirow{3}{*}{25} & \multirow{3}{*}{3} & 257,5 & \multirow{3}{*}{25} & \multirow{3}{*}{32} & \multirow{3}{*}{$\begin{array}{l}625 \\
285\end{array}$} & \multirow{3}{*}{$\begin{array}{r}95 \\
380\end{array}$} & \multirow{3}{*}{$05 / 23$} & \multirow{3}{*}{3500} & \multirow{3}{*}{60} & \multirow{3}{*}{$09 / 27$} & \multirow{3}{*}{3500} & \multirow{3}{*}{45} \\
\hline & & 23 & & & 257,5 & & & & & & & & & & \\
\hline & & 50 & & & 257,5 & & & & & & & & & & \\
\hline
\end{tabular}

Table 6. Urban Planning Instruments and Transportation in the City of Algiers (Author Processing)

\begin{tabular}{|c|c|c|c|c|c|}
\hline \multicolumn{5}{|r|}{ STRATEGIC OBJECTIVES } & THE PRIORITY THEME CROSSED \\
\hline \multirow{8}{*}{ 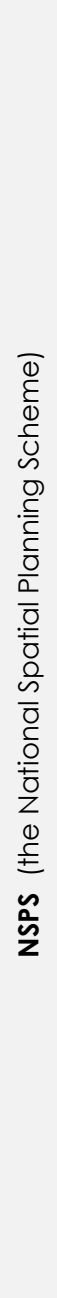 } & \multicolumn{4}{|c|}{ TERRITORIAL } & \multirow{4}{*}{$\begin{array}{l}\text { Transport system and } \\
\text { sustainable mobility }\end{array}$} \\
\hline & \multicolumn{4}{|c|}{$\begin{array}{l}\text { Only Law N 01-13 of } 17 \text { Joumada El Oula } 1422 \text { corresponding to August 17, } 2001 \text { on } \\
\text { orientation and organization of terrestrial transport that addresses the subject of } \\
\text { transport in the NSPS } \\
\text { - Modernization and networking of public works infrastructure, motorway and rail } \\
\text { transport, logistics and communication platforms. }\end{array}$} & \\
\hline & \multirow{6}{*}{ 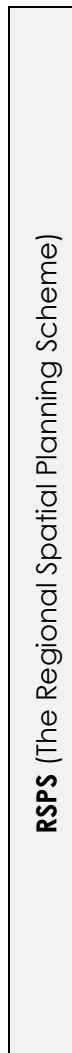 } & \multicolumn{3}{|c|}{ REGIONAL } & \\
\hline & & \multicolumn{3}{|c|}{$\begin{array}{l}\text { Agglomeration organization promoting economic } \\
\text { development, solidarity and integration of populations, } \\
\text { distribution of activities and services and controlled } \\
\text { management of space and urban mobility. }\end{array}$} & \\
\hline & & \multirow{4}{*}{ 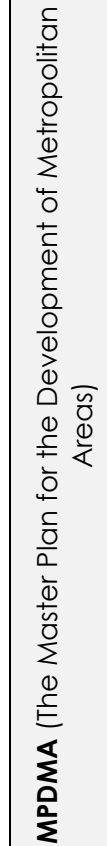 } & \multicolumn{2}{|c|}{ METROPOLITAN } & \multirow{2}{*}{$\begin{array}{l}\text { Urbanization and metro } \\
\text { urban sprawl }\end{array}$} \\
\hline & & & \multicolumn{2}{|c|}{$\begin{array}{l}\text { The location of major transport } \\
\text { infrastructures and major structural equipment } \\
\text { - The general guidelines for the protection } \\
\text { and valorization of the environment } \\
\text { - Create a common culture of spatial } \\
\text { planning across the administrative boundaries of the } \\
\text { territory and sit the bases of a territory project from its } \\
\text { nerve center, which is the metropolitan area. }\end{array}$} & \\
\hline & & & \multicolumn{2}{|c|}{\begin{tabular}{|l|l|}
+ & SPECIFIC \\
\end{tabular}} & \\
\hline & & & 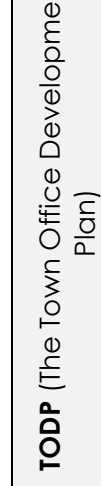 & $\begin{array}{l}\text { Modernization of railway } \\
\text { infrastructure } \\
\text { - The extension of the tram line to } \\
\text { the west of the office town } \\
\text { - Urban transport companies for } 48 \\
\text { Office Town. } \\
\text { - Improvement of public transport } \\
\text { infrastructure and networks. } \\
\text { - The extension of the metro line } 01 \\
\text { to the commune of BAB EZZOUAR... }\end{array}$ & $\begin{array}{l}\text { Development and } \\
\text { modernization }\end{array}$ \\
\hline
\end{tabular}

Source: (NSPS) 2025

(Author Treatment) 